\title{
Treatment costs for the group of patients with non-specific inflammatory bowel disease during acute exacerbation and further annual observation
}

\author{
Koszty leczenia grupy chorych z nieswoista chorobą zapalną jelit \\ w trakcie ostrego rzutu choroby i dalszej rocznej obserwacji \\ Agnieszka Meder ${ }^{1}$, Maciej Świątkowski ${ }^{1}$, Grzegorz Meder², Jarosław Koza ${ }^{1}$, Małgorzata Szamocka ${ }^{1}$ \\ ${ }^{1}$ Clinical Department of Gastroenterology, Vascular Diseases and Internal Medicine, Nicolaus Copernicus University in Toruń, \\ Collegium Medicum in Bydgoszcz, Poland \\ 2Department of Radiology, University Hospital No. 2 in Bydgoszcz, Poland
}

Przegląd Gastroenterologiczny 2011; 6 (1): 36-44 DOI: $10.5114 / p g .2011 .20106$

Key words: treatment costs, non-specific inflammatory bowel disease.

Słowa kluczowe: koszty leczenia, nieswoista choroba zapalna jelit.

\begin{abstract}
Address for correspondence: Agnieszka Meder MD, PhD, Clinical Department of Gastroenterology, Vascular Diseases and Internal Diseases, Collegium Medicum, Nicolaus Copernicus University, Bydgoszcz, Ujejskiego 75, 85-168 Bydgoszcz, tel. +48 523655284 , fax +48 5237149 12, e-mail: agnieszka.meder@wp.pl
\end{abstract}

\begin{abstract}
Introduction: The problem of costs related to health care services is particularly important in the case of chronic diseases, among which non-specific inflammatory bowel diseases (IBD) are classified.

Aim: To analyse the costs of health care services determined by the National Health Fund (NFZ) during annual medical care for patients with IBD from the moment of inception of treatment of acute exacerbation.

Material and methods: The study was conducted in 20042007 in 41 patients diagnosed with Crohn's disease (CD) (14 people) or ulcerative colitis (UC) (27 people).

The study was initiated during an acute exacerbation. At the beginning of the study and during the final visit the history data concerning the occupational activity of the sick person was taken. During the observation the duration of inability to work because of IBD was noted. After a year, information about the amount of health care services and their costs incurred by the NFZ funds was obtained from the hospital database. The study protocol was approved by the Bioethics Committee at the Collegium Medicum of Bydgoszcz.

Results: The average annual cost of treating a patient with IBD calculated on the basis of the income of the Hospital from the NFZ for provided health care services amounted to 10298 PLN (in CD - 12623 PLN and in UC - 9092 PLN). Hospitalizations generated $95.8 \%$ of total costs. Costs of surgical treatment constituted $34.8 \%$ of the costs of hospitalization, and costs of biological treatment $14.5 \%$. The cost of biological and surgical treatment per patient using health care services was comparable and amounted to 20121 PLN (for surgical
\end{abstract}

\section{Streszczenie}

Wstęp: Problem kosztów związanych ze świadczeniami zdrowotnymi nabiera szczególnego znaczenia w przypadku chorób przewlekłych, do których zaliczane są nieswoiste choroby zapalne jelit (inflammatory bowel diseases - IBD).

Cel: Głównym celem pracy była analiza kosztów świadczeń zdrowotnych wycenionych przez Narodowy Fundusz Zdrowia (NFZ) w trakcie rocznej opieki medycznej nad chorymi z IBD od momentu rozpoczęcia leczenia z powodu ostrego rzutu choroby.

Materiat i metody: Badanie prowadzono w latach 2004-2007 u 41 pacjentów z rozpoznaną chorobą Leśniowskiego-Crohna (Crohn's disease - CD) (14 osób) i wrzodziejącym zapaleniem jelita grubego (ulcerative colitis - UC) (27 osób). Badanie rozpoczynano $\mathrm{w}$ okresie ostrego rzutu choroby. Na początku badania oraz podczas wizyty końcowej zbierano wywiad dotyczący aktywności zawodowej chorego. W trakcie obserwacji odnotowywano czas trwania niezdolności do pracy z powodu IBD. Po roku ze szpitalnej bazy danych uzyskano informacje o ilości świadczeń zdrowotnych i ich kosztach poniesionych ze środków finansowych NFZ. Na prowadzenie badania uzyskano zgodę Komisji Bioetycznej przy Collegium Medicum w Bydgoszczy.

Wyniki: Średni roczny koszt leczenia pacjenta z IBD wyliczony na podstawie przychodów szpitala z NFZ za wykonane świadczenia zdrowotne wyniósł 10298 zł (w CD 12623 zt, a w UC 9092 zł). Hospitalizacje generowały 95,8\% kosztów całkowitych. Koszty leczenia chirurgicznego stanowiły 34,8\% kosztów hospitalizacji, a koszty leczenia biologicznego 14,5\%. Koszt leczenia biologicznego i chirurgicznego przypadający na jed- 
treatment) and 19500 PLN (for biological treatment). The highest unit cost concerned the treatment of a patient with acute exacerbation of ulcerative colitis resistant to conventional therapy and was mainly associated with surgical treatment and postoperative complications.

Conclusions: The main direct costs in IBD are associated with hospitalizations, with a high percentage related to surgical and biological treatment. Factors that will reduce the need for hospitalization or shorten its duration are economically beneficial. An alternative to current surgical treatment of patients with non-specific inflammatory bowel disease is biological therapy, which has many advantages. This method of treatment requires careful assessment over time of its application because of the short time since its introduction. In Poland, patients with non-specific inflammatory bowel disease, despite generally low financial outlays for health care and financial underestimation of the health services provided to patients, are treated in accordance with applicable standards.

\section{Introduction}

In the current reality of health care with continuously rising costs of medical care and limited financial possibilities of even the richest societies, analysis of the costs of treatment and diagnosis is extremely important.

Costs associated with the disease can be broadly divided into direct and indirect ones. The direct ones concern the patient's health care, while the indirect ones concern the functioning of the patient in society and are mainly related to his professional activity [1] When making decisions on matters of medical interventions, we should be aware of their indicative costs. We obtain or know the information on direct medical costs for health care services on the basis of results of already carried out research, retrospective cohort studies, expert opinions or published data [1]. Indirect costs are harder to quantify and in many cases they may be more important than direct costs. These include: absence from work and decrease in patient's income due to deterioration of health and lower quality of life due to illness and social costs of relatives taking care of the patient [1]. Economic analyses rely on quantitative comparison of alternative strategies of practices in terms of benefits and costs. The aim is to obtain information needed for therapeutic decision-making and optimal use of limited financial resources for improving patients' health.

The most substantial issues brought up in economic analysis of treatment include: cost minimization analysis; decision-making analysis, that is of maximization of results; cost-benefit analysis; and the cooperation of the patient. In a situation when costs of new drugs are lower and drugs are more effective, the matter of minimization of costs is not a subject for discus- nego pacjenta korzystającego ze świadczenia zdrowotnego był porównywalny i wyniósł 20121 zł (za leczenie chirurgiczne) zł i 19500 zł (za leczenie biologiczne). Najwyższy jednostkowy koszt leczenia dotyczył chorej z opornym na leczenie konwencjonalne ciężkim rzutem UC i związany był głównie z leczeniem operacyjnym i powikłaniami pooperacyjnymi.

Wnioski: Główne koszty bezpośrednie w IBD są związane z hospitalizacjami i z wysokim odsetkiem środków przeznaczonych na leczenie chirurgiczne i biologiczne. Czynniki, które ograniczą potrzebę hospitalizacji lub skrócą czas jej trwania są ekonomicznie korzystne. Alternatywą do dotychczasowego leczenia chirurgicznego chorych na IBD jest leczenie biologiczne, które ma wiele zalet. Ta metoda leczenia ze względu na krótki czas od jej wprowadzenia wymaga jednak starannej oceny w dłuższym czasie stosowania. W Polsce chorzy na IBD, pomimo ogólnie niskich nakładów finansowych na opieke zdrowotną oraz niedoszacowanie finansowe świadczeń zdrowotnych udzielanych tym chorym, leczeni są zgodnie z powszechnie obowiązującymi standardami.

sion. However, for new generation drugs of higher efficiency, but also more expensive, this problem is more complicated. Therefore, economic analysis in these cases is extremely important. The effectiveness of specific medical intervention in the decision-making analysis is usually measured by obtained end-points such as the need for surgery, recovery or death of the patient. It is extremely important for diseases such as myocardial infarction or appendectomy, but its importance in chronic diseases is significantly lower. During the analysis of obtained benefits we often encounter serious problems, because this requires e.g. assignments of defined monetary value to given health states, which may not only be difficult but also ethically questionable.

The concept of usefulness of the intervention is closely associated with the concept of health-related quality of life (HRQoL). These types of analyses are important in the case of chronic diseases. The measure of HRQoL is usually the number of years adjusted to the quality of life, called QALY. The value of QALY is calculated by multiplying the number of years of life by the HRQoL factor given by the patient $(0$ - death to 1 - total health). For example, 10 years of life in health-assessed HRQoL of 0.5 equals 5 QALY. The same value, for example, can be obtained by reducing years of age to 5 years, but with overall health of 1 . Another important economic problem in many chronic diseases concerns patients ignoring doctor's recommendations. This applies to approximately $30-40 \%$ of patients [2]. In the U.S., this factor is the cause of loss of nearly $\$ 100$ billion each year and represents $10 \%$ of hospitalizations. Approximately $70 \%$ of these costs are associated with reduced productivity at work and premature death and the remaining $30 \%$ are direct medical costs $[3,4]$. 
With significantly reduced financial resources in the Polish health care system in comparison with other countries, detailed analysis of the costs of treating chronic, often lifetime-lasting diseases, which young, active people come down with, seems to be an extremely important issue. Such analyses are extremely useful in identifying health care services burdened with the greatest costs, and combined with the assessment of the quality of life they simplify the selection of optimal therapy.

\section{Aim}

The main purpose of this study was to analyse the costs of health care services determined by the National Health Fund (NFZ) during the annual medical care of patients with IBD from the beginning of treatment of acute exacerbation.

\section{Material and methods}

The study was conducted in 2004-2007 in 41 patients diagnosed with non-specific inflammatory bowel disease (IBD). There were 14 people with Crohn's disease (CD) and 27 with ulcerative colitis (UC).

The research subjects were 20 women and 21 men aged from 20 to 60 years (mean 43 years) and the research started during an acute exacerbation. At the beginning and during the final visit, history data about a patient's professional activity was taken. During observation the time of inability to work due to IBD was also reported. After a year, information about the type and quantity of health care services provided to patients and their costs paid by the NFZ was obtained from the hospital database. The obtained data were specifically related to hospitalization because of an acute exacerbation including both surgical and biological treatment. Also one-day hospitalizations were analysed, during which control examinations were performed and treatment was modified, and specialist ambulatory advice was given to patients with IBD.

\section{Results}

The overall annual cost of specialist medical care of the tested group was 422420 PLN. Of this amount, hospitalizations accounted for $95.8 \%$ of the cost, one-day hospitalizations for $2.5 \%$, and ambulatory advice for $1.7 \%$. The average annual cost of treating one patient was 10306 PLN (tab. I). The cost of surgical treatment was $34.8 \%$ of the total cost of hospitalization related to acute exacerbation, the cost of biological treatment $14.5 \%$, and costs of the remaining hospitalizations $50.7 \%$ (tab. II).

The average annual cost of specialist medical care of patients with UC was 9096 PLN (from 154 to 99039 PLN) and patients with CD 12628 PLN (from 1400 to 1940 900 PLN). The costs of specialist ambulatory advice and hospital visits under one-day hospitalizations were $5.6 \%$ in UC and $2.4 \%$ in CD (tab. III and IV). Costs of surgical treatment were $51.7 \%$ of the total cost of hospitalization of patients with UC and $12.1 \%$ of the total cost of

Table I. Total annual cost of specialist medical care of patients from the study group

Tabela I. Catkowity roczny koszt specjalistycznej opieki medycznej nad pacjentami z badanej grupy

\begin{tabular}{lcccc} 
& \multicolumn{2}{c}{ Annual cost of specialist medical care of patients from the study group } \\
\cline { 2 - 5 } & \multicolumn{2}{c}{ General } & $\begin{array}{c}\text { Attributable to one patient } \\
\text { receiving the benefits }\end{array}$ & $\begin{array}{c}\text { Attributable to one patient } \\
\text { from the study group }\end{array}$ \\
\hline Hospitalizations & $404610 \mathrm{PLN}$ & $95.8 \%$ & $11239 \mathrm{PLN}(\mathrm{N}=36)$ & $9869 \mathrm{PLN}(\mathrm{N}=41)$ \\
\hline Ambulatory advice & $7270 \mathrm{PLN}$ & $1.7 \%$ & $180 \mathrm{PLN}(\mathrm{N}=41)$ & $180 \mathrm{PLN}(\mathrm{N}=41)$ \\
\hline One-day hospitalizations & $10540 \mathrm{PLN}$ & $2.5 \%$ & $659 \mathrm{PLN}(\mathrm{N}=16)$ & $257 \mathrm{PLN}(\mathrm{N}=41)$ \\
\hline TOTAL & $422420 \mathrm{PLN}$ & & & $10306 \mathrm{PLN}$
\end{tabular}

Table II. Annual cost of hospital treatment of patients from the study group

Tabela II. Roczny koszt leczenia szpitalnego pacjentów z badanej grupy

\begin{tabular}{|c|c|c|c|}
\hline \multirow[b]{3}{*}{ Hospitalizations without surgical and biological treatment } & \multicolumn{3}{|c|}{ Annual cost of hospital treatment } \\
\hline & \multicolumn{2}{|c|}{ General } & \multirow{2}{*}{$\begin{array}{c}\text { Attributable to one patient } \\
\text { receiving the benefits } \\
7895 \text { PLN }(N=26)\end{array}$} \\
\hline & 205260 PLN & $50.7 \%$ & \\
\hline Surgical treatment & 140850 PLN & $34.8 \%$ & 20121 PLN $(N=7)$ \\
\hline Biological treatment & 58500 PLN & $14.5 \%$ & 19500 PLN $(N=3)$ \\
\hline TOTAL & 404610 PLN & & 11239 PLN $(N=36)$ \\
\hline
\end{tabular}


Table III. Total annual cost of specialist medical care of patients with UC

Tabela III. Catkowity roczny koszt specjalistycznej opieki medycznej nad pacjentami z UC

\begin{tabular}{lcccc} 
& \multicolumn{3}{c}{ Annual cost of treating UC } \\
\cline { 2 - 5 } & General & $\begin{array}{c}\text { Attributable to one patient } \\
\text { receiving the benefits }\end{array}$ & $\begin{array}{c}\text { Attributable to one patient } \\
\text { from the study group }\end{array}$ \\
\hline Hospitalizations & $232050 \mathrm{PLN}$ & $94.4 \%$ & $10548 \mathrm{PLN}(\mathrm{N}=22)$ & $8594 \mathrm{PLN}(\mathrm{N}=27)$ \\
\hline Ambulatory advice & $5086 \mathrm{PLN}$ & $2.1 \%$ & $188 \mathrm{PLN}(\mathrm{N}=27)$ & $188 \mathrm{PLN}(\mathrm{N}=27)$ \\
\hline One-day hospitalizations & $8490 \mathrm{PLN}$ & $3.5 \%$ & $708 \mathrm{PLN}(\mathrm{N}=12)$ & $314 \mathrm{PLN}(\mathrm{N}=27)$ \\
\hline TOTAL & $245626 \mathrm{PLN}$ & & & $9096 \mathrm{PLN}$
\end{tabular}

Table IV. Total annual cost of specialist medical care of patients with CD

Tabela IV. Catkowity roczny koszt specjalistycznej opieki medycznej nad pacjentami z CD

\begin{tabular}{lcccc} 
& \multicolumn{3}{c}{ Annual cost of treating CD } \\
\cline { 2 - 5 } & General & $\begin{array}{c}\text { Attributable to one patient } \\
\text { receiving the benefits }\end{array}$ & $\begin{array}{c}\text { Attributable to one patient } \\
\text { from the study group }\end{array}$ \\
\hline Hospitalizations & $172560 \mathrm{PLN}$ & $97.6 \%$ & $12326 \mathrm{PLN}(\mathrm{N}=14)$ & $12326 \mathrm{PLN}(\mathrm{N}=14)$ \\
\hline Ambulatory advice & $2184 \mathrm{PLN}$ & $1.2 \%$ & $156 \mathrm{PLN}(\mathrm{N}=14)$ & $156 \mathrm{PLN}(\mathrm{N}=14)$ \\
\hline One-day hospitalizations & $2050 \mathrm{PLN}$ & $1.2 \%$ & $513 \mathrm{PLN}(\mathrm{N}=4)$ & $146 \mathrm{PLN}(\mathrm{N}=14)$ \\
\hline TOTAL & $176794 \mathrm{PLN}$ & & & $12628 \mathrm{PLN}$
\end{tabular}

hospitalization of patients with CD (tab. V and VI). Costs of biological treatment, which involved only patients with CD, were $33.9 \%$ of the total costs of hospitalization for acute exacerbation of this disease (tab. V). Patients with ulcerative colitis were not treated biologically because of the absence of registration of such treatment in Poland during the period of study.

Patients during the study were hospitalized because of acute exacerbation or these were one-day hospitalizations associated with the necessity of follow-up examinations and possible modification of treatment. Hospitalizations because of acute exacerbations included 36 persons, representing $81.5 \%$ of the study group. Mostly they were one-time hospitalizations that lasted from 2 to 70 days ( $M e=5$ days). There were 22 hospitalized patients (53.7\%). All patients with CD had been in hospital at least once. Of the patients with ulcerative colitis 5 people $(18.5 \%$ of the study group) did not require hospitalization. Patients with $U C$ had been in hospital from 3 to 26 days ( $M e=9$ days), and patients with CD from 2 to 70 days ( $M e=5$ days). Seven patients with acute exacerbation required surgical treatment. There were 4 women with ulcerative colitis and 2 women and 1 man with CD. These patients stayed together at the surgical ward from 5 to 42 days ( $M e=8$ days). Biological treatment of infliximab was used in 3 patients with Crohn's disease. Due to the procedure of administration of the induction therapy they stayed in hospital three times. One-day hospitalizations related to the follow-up examinations and treatment modification included 16 patients, representing $39.0 \%$ of the study group. In this group of patients there were 12 people with ulcerative colitis and 4 individuals with $C D$, which represents respectively $44.4 \%$ and $28.6 \%$ of patients with the disorder. In the study during the initial and final visit, 15 (36.6\%) persons had been living on a pension,

Table V. Annual cost of hospital treatment of patients with UC

Tabela V. Roczny koszt leczenia szpitalnego pacjentów z UC

\begin{tabular}{lccc} 
& \multicolumn{2}{c}{ Annual cost of hospital treatment of patients with UC } \\
\cline { 2 - 4 } & \multicolumn{2}{c}{ General } & $\begin{array}{c}\text { Attributable to one patient } \\
\text { receiving the benefits }\end{array}$ \\
\hline Hospitalizations without surgical and biological treatment & $112150 \mathrm{PLN}$ & $48.3 \%$ & 5903 PLN $(N=19)$ \\
\hline Surgical treatment & $119900 \mathrm{PLN}$ & $51.7 \%$ & $29975 \mathrm{PLN}(\mathrm{N}=4)$ \\
\hline Biological treatment & 0 PLN & $0.0 \%$ & 0 PLN $(N=0)$ \\
\hline TOTAL & $232050 \mathrm{PLN}$ & 10548 PLN
\end{tabular}


Table Vl. Annual cost of hospital treatment of patients with CD

Tabela VI. Roczny koszt leczenia szpitalnego pacjentów z CD

\begin{tabular}{lccc} 
& \multicolumn{2}{c}{ Annual cost of hospital treatment of patients with CD } \\
\cline { 2 - 4 } & General & $\begin{array}{c}\text { Attributable to one patient } \\
\text { receiving the benefits }\end{array}$ \\
\hline Hospitalizations without surgical and biological treatment & $93110 \mathrm{PLN}$ & $54.0 \%$ & $6651 \mathrm{PLN}(\mathrm{N}=14)$ \\
\hline Surgical treatment & $20950 \mathrm{PLN}$ & $12.1 \%$ & $6983 \mathrm{PLN}(\mathrm{N}=3)$ \\
\hline Biological treatment & $58500 \mathrm{PLN}$ & $33.9 \%$ & $19500 \mathrm{PLN}(\mathrm{N}=3)$ \\
\hline TOTAL & $172560 \mathrm{PLN}$ & & $12326 \mathrm{PLN}$
\end{tabular}

$3(7.3 \%)$ persons were unemployed, 17 (41.5\%) people were professionally active, and 6 (14.6\%) patients were retired. All professionally active people used medical certificates of temporary work disability during the observation. Duration of incapacity to work because of illness ranged from 9 to 240 days in a 12-month follow-up, an average of 89 days. No effect of disease type on the period of sickness absence was noted.

\section{Discussion}

Health professionals deciding about medical intervention are often obliged to include only direct costs of their practices. Information about direct costs of medical activities can be obtained from the economic analysis of performed medical procedures, cohort studies, and retrospective and expert opinions. Indirect costs are harder to quantify, and for many diseases they are more important than direct costs. They are related to decrease of patient's income resulting from the patient's incapacity to work, the use of unemployment benefit or a pension. Loss of earning capacity is one of the most important factors influencing the lower quality of life for patients, especially patients with chronic illness [1]. In the case of IBD indirect costs are very important, because of the nature of symptoms, course and prognosis in these diseases. These diseases mostly affect professionally active persons for whom work is one of the priorities in life. A negative impact of IBD on work and family life was reported by $54 \%$ of patients [5]. According to Blomqvist, indirect costs associated with CD may even be twice as high as direct costs [6]. Bernklev in one of his studies found significantly higher levels of unemployment and the number of medical certificates of temporary work disability in ulcerative colitis in relation to the general population. Unemployment during the 5-year observation in this study was over three times higher than in the general population [7]. In the study group 6 (14.6\%) patients were retired, 15 (36.6\%) having a disability pension, $3(7.3 \%)$ persons were unemployed, and only 17 (41.5\%) patients were professionally active. All professionally active people used medical certificates of temporary work disability during the observation. The length of sick leave ranged from 9 to 240 days in the observation period, an average of 89 days. For comparison, the overall Polish population average sickness absence in 2006 per person was around 38 days, and in 2007 almost 36 days [8]. No effect of type of illness for a period of sickness was noted. In a study performed in the U.S. only $5-10 \%$ of patients with IBD were on a sick leave during the year, and losses associated with it were estimated at between 0.4 and 0.8 billion dollars $[9,10]$.

The reason for such a large percentage of medical certificates of temporary work disability that our patients were granted was related to certain assumptions of the research project, namely that the beginning of the observation was an acute exacerbation often of severe or moderately severe character. In this state of health the patient is always unable to work and usually requires hospitalization.

The average annual cost assessed by the NFZ for specialist medical care associated with treating a patient with IBD was 10306 PLN and varied from 154 to 99039 PLN. The average cost per patient with UC was 9096 PLN, and in the case of CD 12628 PLN. The above data result from the performed valuation for the executed health care services suggested by the payer, which is the National Health Fund in Poland.

The actual cost of medical care in IBD is very difficult to calculate. Worldwide there have been created several algorithms of costs calculated for these diseases. The authors of the most frequently cited study (Hay and Hay) propose the application of this algorithm to the formation of hypothetical costs for patients with $C D$ and UC $[9,10]$. This is a study from the 1990s and therefore the average cost calculated for a hypothetical patient for one year, with a value of $\$ 6,561$ for CD and $\$ 1488$ for UC, is probably underestimated, mainly due to significant progress in the treatment of these diseases and the associated increase in costs. However, the percentage distribution of costs is interesting. Surgical procedures, hospitalizations and medications in this algorithm were 
$81 \%$ of the total cost, diagnostic tests and ambulatory advice $18 \%$, and treatment of parenteral symptoms $5.5 \%$. In both diseases $80 \%$ of the cost was generated by a relatively small group of patients, that is about $20 \%$. These costs were primarily associated with the need for hospitalization of these patients, including the need to operate.

In our study it was found that the percentage of costs associated with hospitalizations due to exacerbations of the disease, including surgical treatment, was even greater and accounted for $95.8 \%$ of the total cost of treatment. It should be noted that 36 people were hospitalized, which represents $81.5 \%$ of the studied group of patients. Costs of ambulatory advice and diagnostic tests performed during one-day hospitalizations accounted for only $4.2 \%$.

One of the most recent analyses, published in 2004, comes from the UK [11]. From this analysis, the sixmonth average cost of care of a patient requiring hospitalization was 7,000 pounds (47 945 PLN), and the average cost of care for patients with IBD who did not require hospitalization was 516 pounds ( 3534 PLN) and ranged from a minimum of 73 pounds ( 500 PLN) to a maximum of 33254 pounds (228 842 PLN). As can be seen, these amounts differ significantly from those determined by the NFZ for patients with IBD. The lowest amount paid from the NFZ in this study was 154 PLN and the maximum was 99039 PLN. It should also be noted that the period of observation covered a period of years, not six months as in the British analysis. In addition, at the initial visit, all patients had exacerbation of the disease, with a high proportion of severe and moderate exacerbations, which of course are associated with higher medical costs. To compare, in the British analysis only $14 \%$ of patients required hospitalization, yet the costs associated with it constituted $49 \%$. In the British study it was also noted that exacerbations requiring hospitalization were associated with up to a 20-fold increase in funding, while exacerbation of the disease which did not require a hospital stay was associated with a much lower, only 2-3-fold increase in funding.

In the study the need for hospitalization concerned $36(85 \%)$ from the group of 41 patients who completed the study. Mostly it was a one-time stay $(53.7 \%$ of patients). All patients with CD were hospitalized at least once because of acute exacerbation. Five people with UC who were participating in the study did not require hospitalization. The length of stay in hospital of patients with ulcerative colitis ranged from 3 to 26 days (mean 9 days), whereas in the case of CD it ranged from 2 to 70 days (average 5 days). The total duration of stay in hospital, including one-day hospitalizations related to diagnosis or modification of treatment, ranged from 0 to 70 days (mean 9 days). In order to reduce the costs associated with hospitalizations it may be appropriate to designate additional criteria such as poor forecasts incorporating patient's age and coexisting diseases, which are not included in the general criteria for assessing the severity of the exacerbation. With these data, perhaps it would be possible to select a group of patients whose attempt at outpatient treatment would not be a threat to life and significant deterioration in health. In order to reduce the extremely costly hospitalizations we should also identify indicators of poor prognosis as early as the first days in hospital, and in case of their absence, unsubscribe a patient from hospital with recommendations for continuing the therapy at home with frequent gastro-clinic checkups until a significant improvement in health is obtained.

Quick and accurate diagnosis of IBD may also limit the number of hospitalizations or shorten their duration. This can be achieved inter alia through education of GPs. The occurrence of alarm symptoms in a patient such as weight loss, anaemia, chronic diarrhoea, blood in stools and severe abdominal pain should prompt a GP to refer these patients urgently to a gastroenterologist. In the group of patients $73.2 \%$ had previously diagnosed irritable bowel syndrome. Assessing retrospectively, in most cases patients were not properly diagnosed with $\mathrm{IBD}$, despite the presence of symptoms suggesting organic disease of the bowel. Early diagnosis of IBD is often associated with better response to conventional therapy and longer remission of the disease.

A factor, proven in numerous studies, which enhances the degree of patient compliance with medical recommendations is good communication with the doctor. The physician should try to gain a patient's trust by showing interest in his or her problems by carefully listening, providing him or her with knowledge about health and empathy. What turns out to be important is access to the attending doctor [12-15]. Patient's awareness of the need for rapid therapeutic intervention in case of exacerbation sometimes allows hospitalization to be avoided. Patients with IBD are a special group because of their specific personality traits and the nature of the problems preventing their normal daily functioning. For young patients, professionally active, often with many family obligations, it is difficult to adapt to visits that are set up a few months earlier in the clinic, especially in the morning. Allowing additional specialist ambulatory advice in times of acute exacerbation could potentially reduce the number of hospitalizations by the rapid and appropriate integration of pharmacological treatment.

In recent years, we have seen rapid development of new therapies in IBD, primarily related to biological 
treatment. Pharmacoeconomic analysis taking into account the quality of life of patients during the treatment period and during follow-up plays a very important role in their assessment, and in the future will be the basis for making therapeutic decisions optimal for the patient and the payer. A valuable research project which, apart from improving health and quality of life, has also proven a reduced number of hospitalizations and operations, was the ACCENT multicentre study using infliximab therapy in patients with $C D$ and fistulas $[16,17]$. As previously mentioned, reduction in the number of hospitalizations and surgical procedures is economical $[9,10,18-21]$. Before the era of biological treatment, most cases of $C D$ refractory to conventional treatment ended up with the need for surgical treatment. Biological treatment, beyond the initial purpose which is the induction of remission, creates therapy that maintains the remission, which obviously reduces the number of necessary surgical interventions. In research conducted so far it has been demonstrated that the quality of life of patients with $C D$, surgically treated, improves significantly, but this is not a long-term improvement. This is due to the natural course of the disease, characterized by recurrences [22]. Tillinger et al. in their study observed a significant improvement in the quality of life only up to 6 months after surgery [23].

The study draws attention to the high proportion of costs of hospitalization of patients with ulcerative colitis reserved for surgical treatment. It amounted to $51.7 \%$. During the study, biological treatment with infliximab in Poland was not used as a treatment of ulcerative colitis because of the lack of registration of this drug in the therapy of this disease. If there was a possibility to use it, in some cases probably we would be able to avoid surgery. In one patient with severe ulcerative colitis and associated gangrenous dermatitis, there were indications for its use. The patient has undergone surgical treatment according to Polish standards, and costs of treatment associated with surgery and postoperative complications were among the highest out of all patients. The effectiveness of infliximab in the treatment of severe attacks of ulcerative colitis was proved in the ACT1 and ACT2 trials, in which nearly $70 \%$ of patients responded to treatment with infliximab in the $8^{\text {th }}$ week after the start of the induction treatment $[24,25]$.

In one study published in 2007, the fate of 83 patients with severe ulcerative colitis treated with infliximab was observed. During the 23-month follow-up, 58 patients avoided surgery to remove the large intestine [26]. Feagan et al. and Reinisch et al. published a further study, which showed an improvement in the quality of life and improvement in efficiency of work in people who have responded positively to treatment with infliximab in severe or moderate attacks of ulcerative colitis $[27,28]$. Also, in previous studies on the treatment of gangrenous dermatitis, the effectiveness of this treatment was proved [29, 30].

The cost of conventional treatment, calculated as the sum of revenues from the NFZ for health services performed in this patient, was 99093 PLN. It was mainly associated with the implementation of numerous surgical procedures, the occurrence of postoperative complications and 31-day stay of the patient in the intensive care unit. The cost of infliximab induction treatment during the period of study for this patient would be 21375 PLN, which is an amount almost five times lower than published. The use of "expensive" biological treatment is likely to prevent the need for operation, the occurrence of further complications, and high costs of treatment, and it certainly improves the quality of life of the patient.

The costs of biological treatment are, however, also high. For 3 (7\%) examined patients they were 58500 PLN, i.e. $14.5 \%$ of all costs associated with hospitalization (404 610 PLN). Costs of surgical treatment applied in 7 (17\%) patients in the study amounted to 140850 PLN, i.e. $34.8 \%$ of the total costs of hospitalization. By counting the cost of one patient, the volumes of biological and surgical treatment are comparable and are for biological therapy 19500 PLN and for surgical treatment 20121 PLN. The mental and physical load is certainly much smaller in the case of biological treatment compared with surgery.

Currently in Poland there are two biological medicines for the treatment of CD - infliximab and humanized antibody anti-TNF adalimumab. The effectiveness of the latter in induction and supportive therapy has been proven in the randomized clinical trials CLASSIC-I and CHARM [31, 32]. In the CHARM study there was also observed a reduction in the number of hospitalizations during the supportive therapy lasting 52 weeks from $13.9 \%$ in the placebo group to $5.9 \%$ in the treated group [33]. It is worth emphasizing the convenient route of application of subcutaneous injection, which is less aggravating for the patient and allows the application on an outpatient basis. In 2008 in Poland the programme for biological anxiety treatment of CD in children and adults, funded by the NFZ, was introduced. This will allow access for more patients during the acute phase of $C D$ to take advantage of this new method, obtaining a complete remission and avoidance of surgery. We can also expect in the near future a price reduction of biological agents due to increasing competition among manufacturers of these medicines. Throughout the world there are numerous studies being conducted on new formulations of a group of biological agents [34]. 


\section{Conclusions}

1. The main direct IBD costs are associated with hospitalizations, with a high proportion incurred for surgery and biological treatment.

2. Factors that will limit the need for hospitalizations or shorten their duration are economically beneficial.

3. An alternative to current surgical treatment of patients with non-specific inflammatory bowel disease is biological therapy, which has many advantages. This method of treatment, however, because of the short time since its introduction, requires careful assessment over the period of its application.

4. In Poland, patients with non-specific inflammatory bowel disease, despite generally low financial outlays for health care and financial underestimation of health services provided to patients, are treated in accordance with generally applicable standards.

\section{References}

1. Feagan BG. Review article: economic issues in Crohn's diseaseassessing the effects of new treatments on health-realted quality of life. Aliment Pharmacol Ther 1999; 13 (Suppl.4): 29-37.

2. Hall N, Rubin G, Hungin A, Dougall A. Medication beliefs among patients with inflammatory bowel disease who report low quality of life: a qualitative study. BMC Gastroenterology 2007; 7: 20.

3. Aliotta SL, Vlasnik JJ, Delor B. Enhancing adherence to longterm medical therapy: a new approach to assessing and treating patients. Adv Ther 2004; 21: 214-31.

4. Dezii CM. Medication noncompliance: what is the problem? Manag Care 2000; 9 (Suppl.): 7-12.

5. Binder V. Prognosis and quality of life in patients with ulcerative colitis and Crohn's disease. Int Disabil Stud 1988; 10: 172-4.

6. Blomqvist P, Ekbom A. Inflammatory bowel diseases: Health care and costs in Sweden in 1994. Scand J Gastroenterol 1997; 32: 1134-9.

7. Bernklev T, Jahnsen J, Henriksen M, et al. Relationship between sick leave, unemployment, disability, and health- related quality of life in patients with inflammatory bowel disease. Inflamm Bowel Dis 2006; 12: 402-12.

8. http://www.zus.pl/files/Absencja2006-2007.pdf

9. Hay AR, Hay JW. Inflammatory bowel disease: medical cost algorithms. J Clin Gastroenterol 1992; 14: 318-27.

10. Hay JW, Hay AR. Inflammatory bowel disease: costs of illness. J Clin Gastroenterol 1992; 14: 309-17.

11. Bassi A, Dodd S, Williamson P, Bodger K. Cost of illness of inflammatory bowel disease in the UK: a single centre retrospective study. Gut 2004; 53: 1471-8.

12. Sewerynek E. Wpływ współpracy lekarza z pacjentem na efektywność leczenia osteoporozy. Terapia 2006; 3: 43-6.

13. Stewart MA. Effective physician-patient communication and health outcome: a review. CMAJ 1995; 152: (Suppl. 9): 1423-33.

14. Trummer UF, Mueller UO, Nowak P. Does physician-patient communication that aims at empowering patients improve clinical outcome? A case study. Patient Educ Couns 2006; 61: 299-306.
15. Yamada T. Aspekty psychospołeczne opieki nad pacjentami z chorobami przewodu pokarmowego. Podręcznik gastroenterologii (Małecka-Panas E. red. wyd. pol.). Czelej, Lublin 2006; 1-4.

16. Hanauer SB, Feagan BG, Lichtenstein GR, et al. Maintenance infliksimab for Crohn's disease: the ACCENT I randomised trial. Lancet 2002; 359: 1541-9.

17. Lichtenstein GR, Yan S, Bala M, et al. Infliximab maintenance treatment reduces hospitalizations, surgeries and procedures in fistulizing Crohn's disease. Gastroenterology 2005; 128: 862-9.

18. Bernstein CN, Papineau N, Zajaczkowski J, et al. Direct hospital costs for patients with inflammatory bowel disease in a Canadian tertiary care university hospital. Am J Gastroenterol 2000; 95: 677-83.

19. Cohen RD. The cost of Crohn's disease: drug or surgery? Biodrugs 2000; 14: 331-244.

20. Feagan BG, Vreeland MG, Larson LR, Bala MV. Annual cost of care for Crohn's disease: A payor perspective. Am J Gastroenterol 2000; 95: 1955-60.

21. Silverstein MD, Loftus EV, Sandborn WJ, et al. Clinical course and costs of care for Crohn's disease: Markov model analysis of a population-based cohort. Gastroenterology 1999; 117: 49-57.

22. Rutgeerts P, Geboes K, Vantrappen G, et al. Predictability of the postoperative course of Croh's disease. Gastroenterology 1990; 99: 956-63.

23. Tillinger $W$, Mittermaier $C$, Lochs $H$, et al. Health-related quality of life in patients with Crohn's disease: influence of surgical operation - a prospective trial. Dig Dis Sci 1999; 44: 932-8.

24. Jarnerot G, Hertervig E, Friis- Liby I, et al. Infliksimab as rescue therapy in severe to moderately severe ulcerative colitis: a randomised, placebo-controlled study. Gastroenterol 2005; 128: 1805-11.

25. Rutgeerts P, Sandborn WJ, Feagan BG, et al. Infliksimab for induction and maintenance therapy for ulcerative colitis. N Engl J Med 2005; 353: 2462-76.

26. Kohn A, Daperno M, Armuzzi A, et al. Infliximab in severe ulcerative colitis: short-term results of different infusion regimens and long-term follow-up. Aliment Pharmacol Ther 2007; 26: 747-56.

27. Feagan BG, Reinisch W, Rutgeerts P, et al. The effects of infliksimab therapy on health-related quality of life in ulcerative colitis patients. Am J Gastroenterol 2007; 102: 794-802.

28. Reinisch W, Sandborn WJ, Bala M, et al. Response and remission are associated with improved quality of life, employment and disability status, hours worked, and productivity of patients with ulcerative colitis. Inflamm. Bowel Dis 2007; 13: 1135-40.

29. Brooklyn T, Dunhill GS, Shetty A, et al. Infliksimab for the treatment of pyoderma gangrenosum: a randomised, double blind placebo controlled trial. Gut 2006; 55: 505-9.

30. Ljung T, Staun M, Grove O, et al. Pyoderma gangrenosum associated with Crohn's disease: effect of TNF alpha blockade with infliksimab. Scand J Gastroenterol 2002; 37: 1108-10.

31. Colombel JF, Sandborn WJ, Rutgeerts P, et al. Adalimumab for maintenance of clinical response and remission in patient with Crohn's disease: the CHARM trial. Gastroenterology 2007; 132: 52-65.

32. MacIntosh DG, Lukas M, Sandborn W, et al. A randomised, double blind, placebo controlled trial of the clinical assessment 
of adalimumab safety and efficacy studied as an induction therapy in Crohn's disease. Gut 2004; 53 (Suppl. VI): A47.

33. Feagan BG, Panaccione R, Sandborn W, et al. An evaluation of adalimumab on the risk of hospitalization in patients with Crohn's disease, data from CHARM. Gastroenterology 2007; 132: A-513.

34. Feagan BG, Sandborn WJ, Hass S, et al. Health-Related Quality of Life During Natalizumab Maintenance Therapy for Crohn's Disease. Am J Gastroenterol 2007; 102: 2737-46. 